\title{
EFEKTIFITAS GROUNDSILL TERHADAP PENYEBARAN SEDIMEN SUNGAI GRINDULU KABUPATEN PACITAN
}

\author{
Susilo Budi ${ }^{1}$, Very Dermawan ${ }^{2}$, Emma Yuliani ${ }^{2}$ \\ ${ }^{1}$ Dinas Bina Marga dan Pengairan Kabupaten Pacitan \\ ${ }^{2}$ Dosen Jurusan Teknik Pengairan, Fakultas Teknik, Universitas Brawijaya, Malang \\ e-mail: suszy_01@yahoo.com, e_yuliani@ub.ac.id,veryderma@yahoo.com
}

\begin{abstract}
ABSTRAK: Sungai Grindulu memiliki potensi bahan galian berupa pasir yang dimanfaatkan sebagai material pembangunan prasarana fisik. Penambangan pasir sungai dapat menyebabkan terjadinya penurunan dasar sungai yang mengakibatkan kerusakan infrastruktur umum. Salah satu upaya yang dilakukan untuk mengendalikan penurunan dasar sungai adalah pembangunan groundsill. Penelitian ini menganalisis penyebaran sedimen di sungai Grindulu sebelum dan sesudah pembangunan groundsill serta pengaruh penambangan pasir terhadap perubahan dasar sungai menggunakan bantuan perangkat lunak HEC-RAS 4.1.0. Hasil simulasi menunjukkan bahwa tanpa groundsill, dasar sungai mengalami degradasi rata-rata $0,602 \mathrm{~m}$ dan agradasi rata-rata $0,505 \mathrm{~m}$. Dengan groundsill tanpa penambangan pasir, terjadi degradasi rata-rata $0,659 \mathrm{~m}$ dan agradasi rata-rata $0,483 \mathrm{~m}$. Dengan groundsill dan penambangan pasir, terjadi degdarasi rata-rata $1,017 \mathrm{~m}$ dan agradasi rata-rata $0,627 \mathrm{~m}$. Direkomendasikan lokasi penambangan baru dengan kapasitas produksi $65 \mathrm{~m}^{3} / \mathrm{hari}$. Dalam periode 5 dan 10 tahun yang akan datang, simulasi angkutan sedimen berdasarkan rekomendasi lokasi dan kapasitas penambangan pasir baru menunjukkan bahwa terjadi degradasi rata-rata $0,569 \mathrm{~m}$ dan $0,846 \mathrm{~m}$. Sedangkan agradasi yang terjadi rata-rata sebesar $0,487 \mathrm{~m}$ dan $0,545 \mathrm{~m}$.
\end{abstract}

Kata kunci: sedimen, HEC-RAS, penambangan pasir, degradasi, agradasi

\begin{abstract}
Grindulu river has potential minerals of sand that used as material of physical infrastructure construction. River sand mining causes riverbed degradation that result damage of public infrastructure. One of the efforts made to control riverbed degradation is construction of groundsill. This study analyze sediment distribution in Grindulu river before and after groundsill construction and the effect of sand mining on riverbed changes using HEC-RAS 4.1.0 software. The simulation result shows that without groundsill, the average of riverbed degradation is 0.602 $m$ and average of aggradation is $0.505 \mathrm{~m}$. With groundsill and without sand mining, the average of riverbed degradation is $0.659 \mathrm{~m}$ and average of aggradation is $0,483 \mathrm{~m}$. With groundsill and sand mining, the average of riverbed degdaration is $1,017 \mathrm{~m}$ and average of aggradation is $0.627 \mathrm{~m}$. New site of sand mining recommended with production capacity of $65 \mathrm{~m}^{3} /$ day. In the period of next 5 and 10 years, sediment transport simulations based on recommended location and capacity of new sand mining site show that the average of riverbed degradation is $0.569 \mathrm{~m}$ and $0.846 \mathrm{~m}$. While the average of aggradation is $0.487 \mathrm{~m}$ and $0.545 \mathrm{~m}$.
\end{abstract}

Keywords: sediment, HEC-RAS, river sand mining, degradation, aggradation

Sungai Grindulu sepanjang $\pm 63,73 \mathrm{~km}$ mengalir di wilayah Kabupaten Pacitan dan bermuara di Samudera Hindia dengan luas DAS mencapai $\pm 733,50 \mathrm{~km}^{2}$. Sungai tersebut mempunyai potensi bahan galian mineral berupa pasir yang telah lama dimanfaatkan sebagai pemasok kebutuhan material untuk pembangunan prasarana fisik.
Permasalahan di sungai muncul ketika tingkat penambangan material/pasir sungai menyebabkan penurunan dasar sungai dan berakibat pada kerusakan infrastruktur umum seperti jembatan, jaringan pipa dan utilitas lainnya. Salah satu upaya yang dilakukan untuk mengendalikan perubahan dasar sungai adalah dengan pembangunan groundsill. 
Penelitian ini menganalisis penyebaran sedimen di sungai Grindulu baik sebelum maupun sesudah pembangunan groundsill serta pengaruh penambangan pasir sungai terhadap perubahan dasar sungai.

Tujuan penelitian ini adalah mengetahui penyebaran sedimen di Sungai Grindulu pada tahun 2016 sebelum dan sesudah adanya pembangunan groundsill, mengetahui lokasi yang sesuai untuk penambangan pasir, dan memperkirakan besarnya perubahan elevasi dasar Sungai Grindulu pada tahun 2021 dan 2026.

Sedimentasi adalah proses pengendapan material yang terangkut aliran air dari bagian hulu sebagai akibat dari erosi. Sungai-sungai mengangkut sedimen dalam setiap alirannya.

Sedimen bisa berada pada berbagai lokasi dalam aliran, tergantung dari keseimbangan antara kecepatan ke atas partikel (gaya angkat dan gaya tarik) serta kecepatan endap partikel (Asdak, 2007).

Tujuan pokok dari pengetahuan tentang angkutan sedimen adalah untuk mengetahui apakah suatu sungai pada kondisi tertentu akan mengalami penggerusan (degradasi), pengendapan (agradasi) atau mengalami angkutan seimbang (equillibrium transport), serta memperkirakan jumlah material yang terangkut dalam proses tersebut.

Bukti ilmiah telah menunjukkan bahwa iklim telah mengalami perubahan. Antara tahun 1906-2005, rata-rata suhu permukaan global meningkat dengan laju $0,74^{\circ} \mathrm{C} \pm 0,18^{\circ}$ (IPCC, 2007) dan mengakibatkan perubahan iklim di berbagai tempat di dunia termasuk di Indonesia. Sebagai akibat dari pemanasan iklim global menyebabkan peningkatan frekuensi dan intensitas kejadian iklim ekstrim. Karena hal tersebut, maka dalam analisis penelitian ini dipertimbangkan pengaruh perubahan iklim terhadap tinggi muka air laut dan debit sungai.

\section{BAHAN DAN METODE}

\section{Lokasi Penelitian}

Sungai Grindulu di Kabupaten Pacitan merupakan bagian dari Wilayah Sungai (WS) Bengawan Solo. Secara astronomis, DAS Grindulu terletak pada $07^{\circ} 57^{\prime} 00^{\prime \prime}$ LS $08^{\circ} 03^{\prime} 00^{\prime \prime}$ LS dan $111^{\circ} 16^{\prime} 30^{\prime \prime}$ BT $111^{\circ} 21^{\prime} 00^{\prime \prime} \mathrm{BT}$.

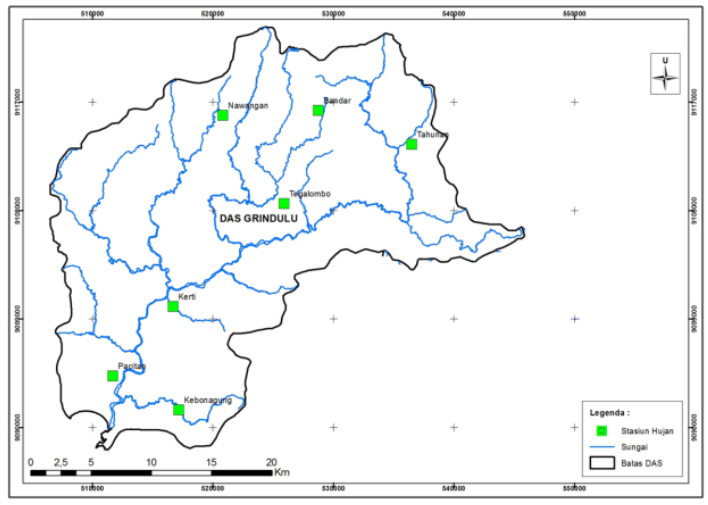

Gambar 1. DAS Grindulu

\section{Bahan Penelitian}

Data-data yang digunakan dalam penelitian sebagai berikut:

1. Data Sekunder

a. Data geometri sungai tahun 2014

b. Data debit Sungai Grindulu tahun 2001 sampai dengan tahun 2015

c. Data pasang surut tahun 2014 dan tahun 2015

2. Data Primer

a. Data sedimen melayang dan material sedimen dasar sungai

b. Data debit sesaat yang diukur bersama dengan waktu pengukuran konsentrasi sedimen melayang

c. Data geometri sungai tahun 2016

d. Data pengukuran dimensi groundsill di lapangan

e. Data penambangan pasir eksisting

\section{Analisa Hidrologi}

\section{Metode Pembangkitan Data Thomas Fiering}

Untuk mengisi data debit yang hilang atau kosong, digunakan Model Thomas Fiering yang mampu meramalkan data beberapa tahun ke depan dengan persamaan:

$Q_{i+1}=\overline{Q_{J+1}}+b_{j}\left(Q_{i}-\overline{Q_{J}}\right)+t_{i} \sigma_{j+1} \sqrt{\left(1-r_{j}^{2}\right)}$

dengan:

$i=$ urutan dalam rangkaian data

$j \quad=$ urutan tahap $(1,2,3, \ldots, \mathrm{k})$

$n=$ jumlah target rangkaian data yang akan dibangkitkan

$Q_{i+1}=$ nilai pada suatu tahap bulan ke i+1 yang akan dibangkitkan

$\overline{Q_{J+1}}=$ nilai rerata pada tahap bulan ke j+1

$b_{j} \quad=$ adalah koefisien regresi least-square 
$t_{i}=$ bilangan random pada urutan ke-i dalam rangkaian data dengan rerata nol dan simpangan baku satu dan mengikuti distribusi normal

$\sigma_{j+1}=$ simpangan baku pada tahap tersebut

$r_{j} \quad=$ koefisien korelasi

\section{Analisis Frekuensi}

Analisis frekuensi bisa diterapkan pada data debit sungai maupun data hujan. Data yang digunakan dapat berupa data debit atau hujan maksimum tahunan, yaitu data paling besar yang terjadi dalam periode satu tahun yang diukur selama beberapa tahun (Triatmodjo, 2010).

Dalam penelitian ini, analisis frekuensi digunakan untuk memperkirakan besarnya debit rancangan pada kala ulang tertentu dengan menggunakan metode Log Pearson Tipe III.

$\log X=\overline{\log X}+K \cdot S_{x}$

dengan:

$\log X=$ nilai logaritmik debit $\mathrm{x}$ dengan periode ulang $\mathrm{T}$

$\overline{\log X}=$ rata-rata nilai logaritma debit $\mathrm{x}$

$K=$ karakteristik dari distribusi LogPearson Tipe III

Sx $=$ standar deviasi dari $\log \mathrm{X}$

\section{Uji Kesesuaian Distribusi Frekuensi}

Tujuan dari uji kesesuaian distribusi frekuensi adalah untuk mengetahui apakah distribusi frekuensi yang dipilih bisa digunakan atau tidak pada serangkaian data yang tersedia. Uji kesesuaian distribusi frekuensi terdiri dua macam yaitu Chi Kuadrat dan Smirnov Kolmogorov.

1. Uji Chi Kuadrat

$$
X^{2}=\sum_{t=1}^{t} \frac{(O f-E f)^{2}}{E f}
$$

dengan:

$X^{2}=$ parameter chi kuadrat terhitung

$E f=$ frekuensi teoritis kelas $\mathrm{K}$

Of = frekuensi pengamatan kelas $\mathrm{K}$

Nilai $\mathrm{X}^{2}$ hitung harus lebih kecil dari nilai $\mathrm{X}_{\mathrm{cr}}^{2}$ (Chi Kuadrat Kritis).

2. Uji Smirnov Kolmogorof
$\Delta_{\text {maks }}=|\mathrm{Pe}-\mathrm{Pt}|$
$\Delta=$ selisih maksimum antara peluang teoritis dan empiris
$\mathrm{Pe}=$ peluang empiris
$\mathrm{Pt}=$ peluang teoritis
Distribusi dianggap sesuai jika $\Delta_{\text {maks }}<\Delta_{\text {cr. }}$.

\section{Penentuan Debit Dominan}

Beberapa pengertian debit dominan (Keshavarzy dan Nabavi, 2006) antara lain:

a. Debit yang paling efektif untuk transportasi sedimen.

b. Debit bankfull atau debit sungai yang hanya mengisi saluran utama dan tidak melampaui dataran banjir.

c. Debit banjir dengan frekuensi tetap seperti 1-2 tahun.

d. Debit yang menunjukkan korelasi statistik terbaik dengan berbagai karakteristik morfologi sungai.

Wolman dan Leopold (1957) memberikan rekomendasi bahwa debit dominan adalah debit bankfull dengan kala ulang 1-2 tahun $\left(\mathrm{Q}_{\mathrm{bf}}\right.$ $\left.=\mathrm{Q}_{1-2 \mathrm{tahun}}\right)$.

\section{Analisa Data Pasang Surut}

Skenario yang dipakai dalam pemodelan ini adalah melakukan simulasi angkutan sedimen sungai pada 3 (tiga) kondisi tinggi muka air di hilir sungai yaitu: tinggi muka air pasang (HWL), tinggi muka air rata-rata (SWL), tinggi muka air surut (SWL).

\section{Analisa Sedimen}

\section{Pengambilan Sampel Sedimen}

Sampel sedimen yang diambil dalam penelitian meliputi sampel sedimen melayang (suspended load) dan material dasar sungai (bed material).

Besarnya konsentrasi sedimen melayang (suspended load) di ukur menggunakan alat suspended solid analyzer di lokasi AWLR Sungai Grindulu bersama dengan pengukuran debit kemudian dibuat grafik hubungan debit $\left(\mathrm{Q}_{\mathrm{w}}\right)$ dan konsentrasi sedimen melayang $\left(\mathrm{C}_{\mathrm{s}}\right)$.

Dari grafik tersebut selanjutnya dibuat kurva lengkung kapasitas sedimen yang menggambarkan hubungan debit aliran $\left(Q_{w}\right)$ dengan debit sedimen $\left(\mathrm{Q}_{\mathrm{s}}\right)$.

Menurut Asdak (2007), debit sedimen dapat dihitung sebagai hasil perkalian antara konsentrasi dan debit air yang dirumuskan sebagai berikut:

Qs $=0.0864 \times \mathrm{C} \times \mathrm{Q}_{\mathrm{w}}$

dengan:

Qs = debit sedimen (ton/hari)

$\mathrm{C}=$ konsentrasi

$\mathrm{Q}=$ debit aliran $\left(\mathrm{m}^{3} /\right.$ detik $)$

\section{Pengujian Sampel Sedimen}

Pengujian di laboratorium meliputi: 
1. Uji Berat Jenis (specific gravity)

2. Uji Saringan (Sieve Analysis)

\section{Pengolahan Data}

Tahapan pengolahan data penelitian ini adalah sebagai berikut:

1. Mengisi data debit yang hilang/kosong.

2. Menghitung besarnya debit rancangan.

3. Menentukan debit dominan.

4. Melakukan analisa sampel sedimen.

5. Membangun model HEC RAS sesuai kondisi eksisting meliputi penyiapan dan input data-data model (data debit, data pasang surut, data geometri sungai, dan data sedimen).

6. Kalibrasi hidrodinamika aliran model dengan variasi koefisien kekasaran manning (n).

7. Simulasi angkutan sedimen dari tahun 2014 sampai dengan tahun 2016 dengan bangunan groundsill dan penambangan pasir. Persamaan angkutan sedimen yang digunakan yaitu: Ackers-White, EnglundHansen, Laursen (Copeland), Meyer-PeterMuller, Tofaletti, Yang.

8. Pemilihan persamaan angkutan sedimen yang sesuai kondisi lapangan dengan uji RMSE.

9. Simulasi angkutan sedimen dari 2014 sampai dengan 2016 tanpa bangunan groundsill.

10. Simulasi angkutan sedimen pada kondisi sungai setelah pembangunan groundsill tanpa penambangan pasir.

11. Rekomendasi lokasi dan besarnya volume penambangan pasir.

12. Simulasi angkutan sedimen periode 5 dan 10 tahun yang akan datang.

13. Analisis hasil simulasi dan pembahasan.

14. Kesimpulan dan rekomendasi.

\section{HASIL DAN PEMBAHASAN}

\section{Data Debit}

Penelitian ini menggunakan data debit harian maksimum Sungai Grindulu tahun 2001 sampai dengan tahun 2015 hasil pencatatan pos AWLR Arjowinangun. Data debit untuk penelitian dapat dilihat pada Tabel 1.

Dari tabel tersebut diketahui bahwa terdapat kekosongan data debit harian maksimum pada tahun 2008. Untuk itu perlu dilakukan pengisian data yang kosong tersebut untuk digunakan menentukan debit banjir rancangan Sungai Grindulu.

\section{Pembangkitan Data Debit Yang Kosong}

Pembangkitan data debit sungai Grindulu yang kosong pada tahun 2008 dengan metode Thomas-Fiering dilakukan menggunakan data debit tahun 2001 sampai dengan 2007.

Dari hasil perhitungan pembangkitan data diperoleh nilai debit harian maksimum tahunan sungai Grindulu pada tahun 2008 adalah sebesar $858,219 \mathrm{~m}^{3} / \mathrm{dt}$ dapat dilihat pada Tabel 2 dan Gambar 2.

\section{Analisis Debit Banjir Rancangan}

Besarnya debit banjir rancangan dihitung menggunakan metode Log Pearson Tipe III.

Berdasarkan hasil analisa frekuensi diperoleh nilai debit banjir rancangan sungai Grindulu pada berbagai kala ulang seperti pada Tabel 3.

\section{Debit Dominan}

Debit dominan yang digunakan untuk simulasi angkutan sedimen adalah debit bankfull dengan kala ulang 2 tahun sebagai berikut:

1. Debit dengan kala ulang 2 tahun sebesar $510,94 \mathrm{~m}^{3} / \mathrm{dt}$.

2. Debit maksimal di atas debit kala ulang 2 tahun sebesar 1.990,13 $\mathrm{m}^{3} / \mathrm{dt}$.

3. Rata-rata debit maksimal dan debit kala ulang 2 tahun sebesar $1.250,54 \mathrm{~m}^{3} / \mathrm{dt}$.

Tabel 1. Data Debit Harian Maksimum Sungai Grindulu

\begin{tabular}{|c|c|c|}
\hline No. & Tahun & Debit Harian Maksimum $\left(\mathrm{m}^{3} / \mathrm{dt}\right)$ \\
\hline 1 & 2001 & 271.67 \\
\hline 2 & 2002 & 249.15 \\
\hline 3 & 2003 & 186.61 \\
\hline 4 & 2004 & 560.45 \\
\hline 5 & 2005 & 377.36 \\
\hline 6 & 2006 & 309.94 \\
\hline 7 & 2007 & $1,990.13$ \\
\hline 8 & 2008 & Tidak ada data \\
\hline 9 & 2009 & $1,348.48$ \\
\hline 10 & 2010 & 884.62 \\
\hline 11 & 2011 & 796.68 \\
\hline 12 & 2012 & 598.43 \\
\hline 13 & 2013 & 560.45 \\
\hline 14 & 2014 & 604.38 \\
\hline 15 & 2015 & 249.15 \\
\hline
\end{tabular}

Sumber: BBWS Bengawan Solo 
Tabel 2. Hasil Pengisian Data Debit Tahun 2008 Metode Thomas Fiering

\begin{tabular}{|c|c|c|c|c|c|c|c|}
\hline Tahun & Jan. & Feb. & Mar. & Apr. & Mei & Juni & $\begin{array}{c}\text { Maksimum } \\
\text { Tahunan }\end{array}$ \\
\hline 2001 & 67.220 & 74.891 & 7.998 & 2.613 & 1.488 & 0.042 & 74.891 \\
\hline 2002 & 249.155 & 64.755 & 214.083 & 9.244 & 1.488 & 0.576 & 249.155 \\
\hline 2003 & 151.171 & 186.612 & 16.830 & 1.575 & 1.040 & 0.465 & 186.612 \\
\hline 2004 & 31.580 & 186.612 & 143.801 & 82.976 & 55.357 & 5.207 & 186.612 \\
\hline 2005 & 82.976 & 80.235 & 53.122 & 53.122 & 0.190 & 77.540 & 82.976 \\
\hline 2006 & 309.945 & 212.311 & 154.924 & 194.994 & 119.458 & 9.244 & 309.945 \\
\hline 2007 & 174.384 & 221.246 & 1416.159 & 299.353 & 7.491 & 119.458 & 1416.159 \\
\hline $\mathbf{2 0 0 8}$ & $\mathbf{1 8 5 . 9 9 1}$ & $\mathbf{1 5 7 . 8 9 8}$ & $\mathbf{6 6 3 . 5 8 2}$ & $\mathbf{3 1 2 . 8 3 5}$ & $\mathbf{7 1 . 6 0 4}$ & $\mathbf{3 9 . 3 3 3}$ & $\mathbf{6 6 3 . 5 8 2}$ \\
\hline Tahun & Juli & Agust. & Sept. & Okt. & Nop. & Des. & $\begin{array}{c}\text { Maksimum } \\
\text { Tahunan }\end{array}$ \\
\hline 2001 & 0.273 & 0.028 & 0.061 & 73.844 & 271.674 & 23.629 & 271.674 \\
\hline 2002 & 0.590 & 0.537 & 1.575 & 2.438 & 4.800 & 60.907 & 60.907 \\
\hline 2003 & 5.207 & 0.860 & 0.433 & 1.404 & 122.798 & 129.615 & 129.615 \\
\hline 2004 & 0.590 & 0.676 & 0.676 & 0.328 & 26.672 & 560.455 & 560.455 \\
\hline 2005 & 36.903 & 0.087 & 0.035 & 23.629 & 1.273 & 377.364 & 377.364 \\
\hline 2006 & 0.328 & 0.087 & 0.087 & 0.028 & 0.219 & 57.637 & 57.637 \\
\hline 2007 & 1.404 & 0.007 & 0.001 & 11.181 & 82.976 & 1990.130 & 1990.130 \\
\hline $\mathbf{2 0 0 8}$ & $\mathbf{2 8 . 3 8 9}$ & $\mathbf{0 . 3 9 8}$ & $\mathbf{0 . 4 6 5}$ & $\mathbf{4 1 . 4 7 9}$ & $\mathbf{6 4 . 2 5 8}$ & $\mathbf{8 5 8 . 2 1 9}$ & $\mathbf{8 5 8 . 2 1 9}$ \\
\hline
\end{tabular}

Sumber: Hasil Perhitungan

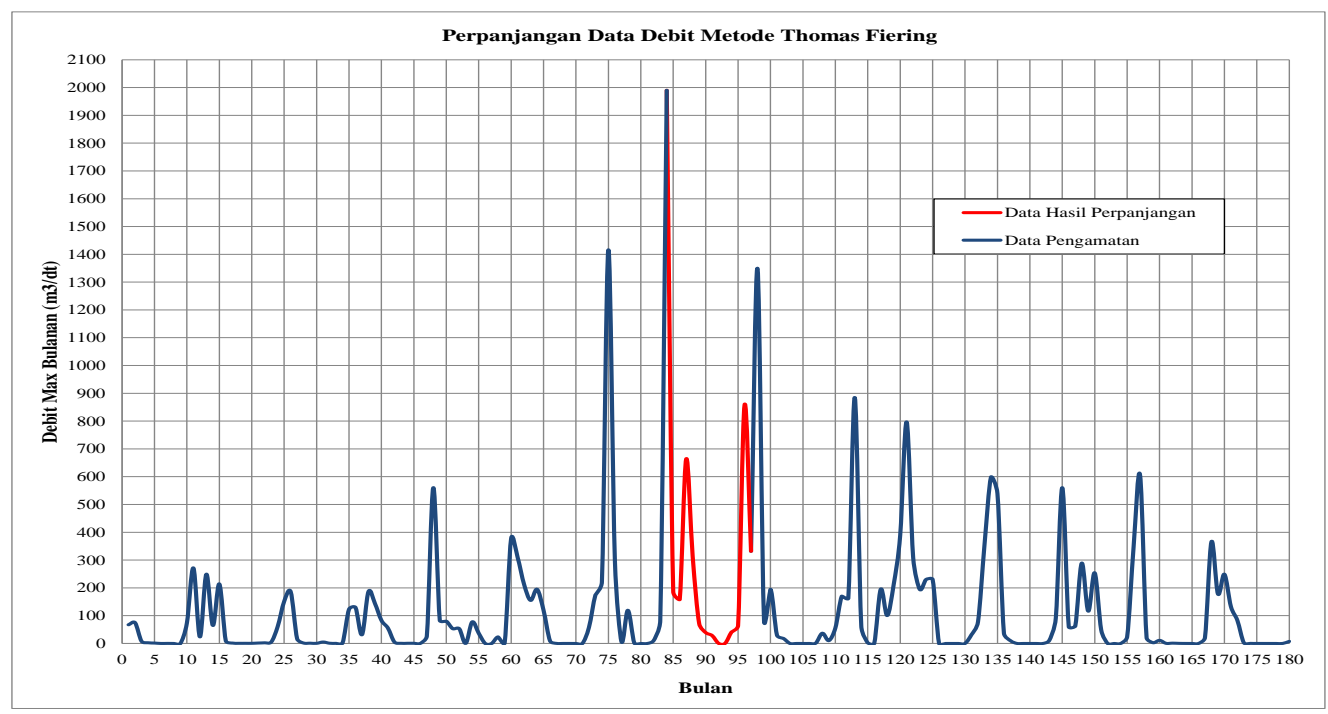

Gambar 2. Grafik Debit Maksimum Bulanan Sungai Grindulu Sumber: Hasil Perhitungan

Tabel 3. Debit Rancangan Sungai Grindulu

\begin{tabular}{|c|c|c|}
\hline No. & $\begin{array}{c}\text { Kala Ulang } \\
(\text { tahun })\end{array}$ & $\begin{array}{c}\text { Debit } \\
\left(\mathrm{m}^{3} / \mathrm{dt}\right)\end{array}$ \\
\hline 1 & 1.01 & 125.96 \\
\hline 2 & 1.05 & 183.57 \\
\hline 3 & 1.11 & 226.89 \\
\hline 4 & 1.25 & 296.35 \\
\hline 5 & 2 & 510.94 \\
\hline 6 & 5 & 921.31 \\
\hline 7 & 10 & $1,276.59$ \\
\hline 8 & 20 & $1,625.26$ \\
\hline 9 & 25 & $1,833.82$ \\
\hline 10 & 50 & $2,336.15$ \\
\hline 11 & 100 & $2,918.68$ \\
\hline 12 & 1000 & $5,613.59$ \\
\hline
\end{tabular}

Sumber: Hasil Perhitungan Analisa Data Pasang Surut

Kondisi muka air pasang surut sebagai input kondisi batas hilir yaitu untuk HWL = $2,40 \mathrm{~m}, \mathrm{MWL}=1,20 \mathrm{~m}$, dan $\mathrm{LWL}=0,00 \mathrm{~m}$.

\section{Analisa Data Sedimen \\ Sedimen Melayang (Suspended Sediment)}

Konsentrasi sedimen melayang di ukur bersamaan dengan pengukuran debit mulai tanggal 16 Maret 2016 sampai dengan 15 Juni 2016. Grafik hubungan debit $\left(\mathrm{Q}_{\mathrm{w}}\right)$ dan konsentrasi sedimen melayang $\left(\mathrm{C}_{\mathrm{s}}\right)$ dapat dilihat pada Gambar 3.

Kurva lengkung kapasitas sedimen dapat dilihat pada Gambar 4. 


\section{Material Sedimen Dasar (Bed Material)}

Sampel material sedimen dasar sungai diambil menyebar di 9 (sembilan) titik pada lokasi penelitian berdasarkan kemudahan dan keamanan akses menuju lokasi. Selanjutnya dilakukan analisa saringan (sieve analysis) dan pengujian berat jenis. Gambar lokasi dan hasil pengujian sampel sedimen dasar sungai dapat dilihat pada Gambar 5 dan Gambar 6.

Hasil analisa saringan menunjukkan bahwa material dasar sungai termasuk dalam klasifikasi pasir (sand) dan kerikil (gravel) dengan diameter butiran berkisar antara 0,0625 mm sampai dengan $64 \mathrm{~mm}$ dengan gradasi butiran yang cukup baik ditunjukkan dengan bentuk kurva distribusi ukuran butiran tanah yang cukup landai.

Hasil analisa saringan tersebut juga bisa digunakan untuk menentukan kesesuaian antara diameter butiran pada lokasi penambangan baru yang direkomendasikan dengan lokasi penambangan eksisting.

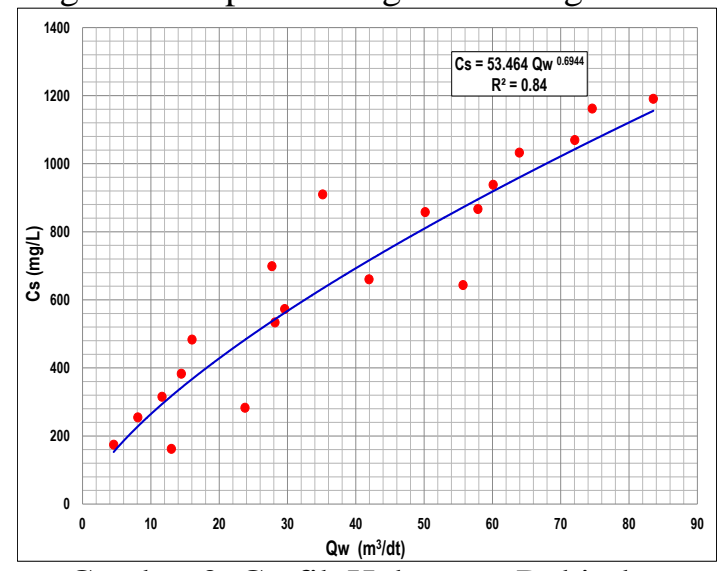

Gambar 3. Grafik Hubungan Debit dan

Konsentrasi Sedimen Melayang Sumber: Hasil Perhitungan

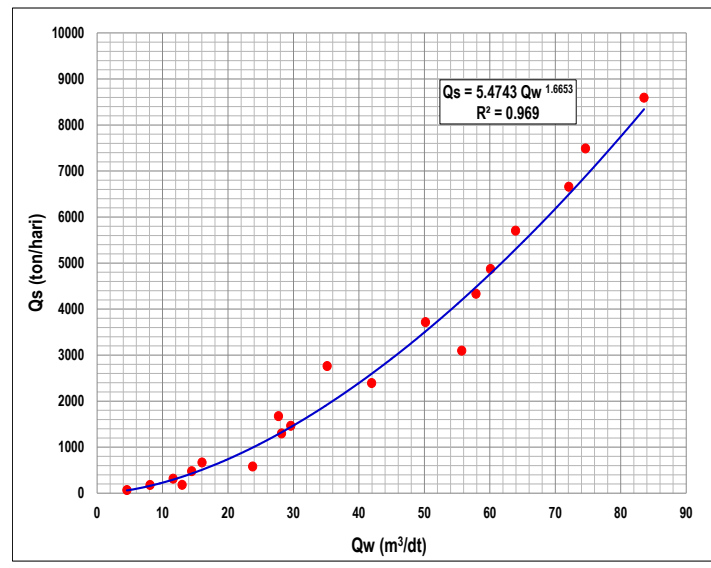

Gambar 4. Kurva Lengkung Kapasitas Sedimen Melayang Sungai Grindulu Sumber: Hasil Perhitungan

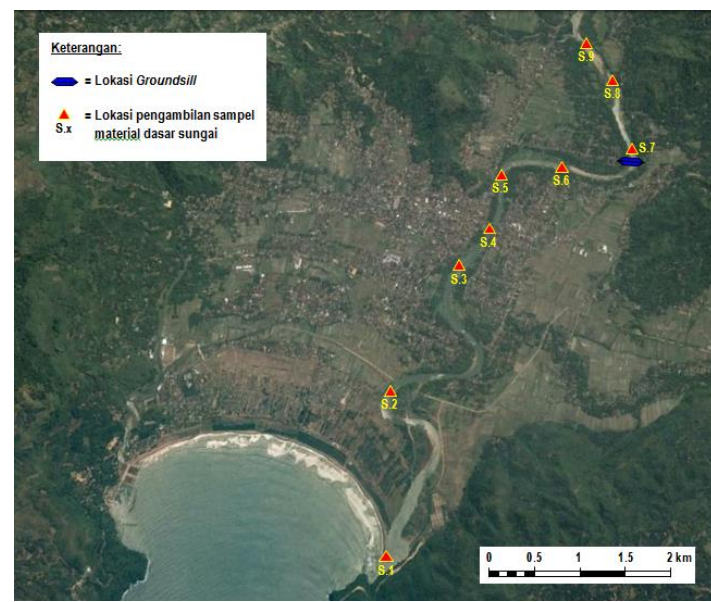

Gambar 5. Lokasi Pengambilan Sampel Material Dasar Sungai Sumber: Penelusuran Lapangan

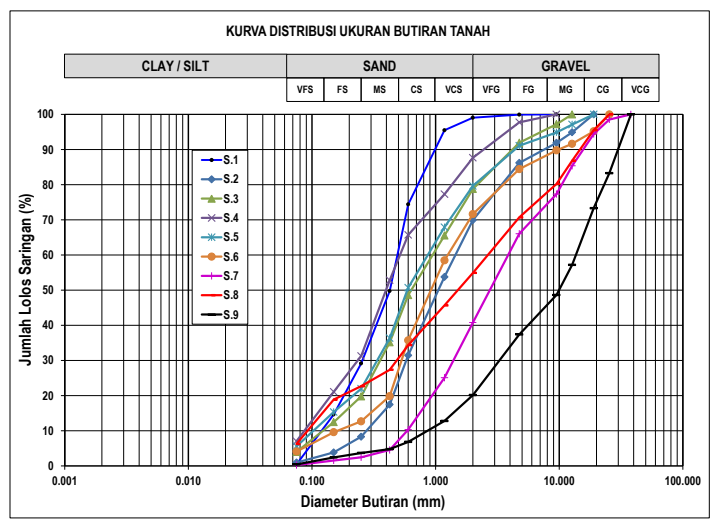

Gambar 6. Kurva Distribusi Ukuran Butiran

Tanah Sungai Grindulu

Sumber: Hasil Perhitungan

\section{Simulasi Angkutan Sedimen dengan Groundsill dan Penambangan Pasir}

Di lapangan, lokasi groundsill berada di antara patok G.80 dan G.81. Simulasi angkutan sedimen dilakukan menggunakan 2 (dua) Fall Velocity Method yaitu Ruby dan Toffaleti pada 3 (tiga) kondisi batas hilir untuk masingmasing persamaan angkutan sedimen yaitu: pasang tertinggi (HWL), pasang rata-rata (SWL), dan pasang terendah (LWL) untuk masing-masing debit simulasi.

Berdasarkan hasil simulasi kondisi eksisting dengan berbagai perubahan parameter model, maka diperoleh hasil uji RMSE seperti pada Tabel 5.

Dari tabel tersebut dipilih model angkutan sedimen yang memiliki nilai uji RMSE terendah yaitu sebesar 0,316 dengan persamaan England-Hansen pada kondisi muka air laut rata-rata (SWL) yang akan digunakan untuk simulasi angkutan sedimen pada kondisi lainnya. 
Tabel 4. Rekapitulasi Hasil Uji RMSE

\begin{tabular}{|c|c|c|c|c|c|c|c|c|}
\hline \multirow{3}{*}{ No. } & \multirow{3}{*}{$\begin{array}{c}\text { Persamaan } \\
\text { Angkutan Sedimen }\end{array}$} & \multirow{3}{*}{$\begin{array}{c}\text { Kondisi Muka } \\
\text { Air Laut }\end{array}$} & \multicolumn{6}{|c|}{ Hasil Uji RMSE } \\
\hline & & & \multicolumn{3}{|c|}{ Ruby } & \multicolumn{3}{|c|}{ Toffaleti } \\
\hline & & & $\mathbf{Q}_{2 \text { th }}$ & $Q_{\text {rata2 }}$ & $\mathbf{Q}_{\max }$ & $\mathbf{Q}_{2 \mathrm{th}}$ & $\mathbf{Q}_{\text {rata2 }}$ & $\mathbf{Q}_{\max }$ \\
\hline \multirow[t]{3}{*}{1} & Ackers-White & HWL & 0.483 & 0.747 & 1.281 & 0.503 & 0.712 & 1.288 \\
\hline & & SWL & 0.475 & 0.679 & 1.290 & 0.468 & 0.722 & 1.295 \\
\hline & & LWL & 0.494 & 0.766 & 1.290 & 0.483 & 0.666 & 1.295 \\
\hline \multirow[t]{3}{*}{2} & England-Hansen & HWL & 0.349 & 0.912 & 1.606 & 0.377 & 1.012 & 1.647 \\
\hline & & SWL & 0.351 & 1.048 & 1.772 & 0.316 & 1.102 & 1.713 \\
\hline & & LWL & 0.363 & 1.132 & 1.814 & 0.355 & 1.147 & 1.832 \\
\hline \multirow[t]{3}{*}{3} & Laursen (Copeland) & HWL & 0.529 & 1.088 & 1.114 & 0.494 & 1.141 & 1.261 \\
\hline & & SWL & 0.606 & 1.011 & 1.112 & 0.611 & 1.037 & 1.256 \\
\hline & & LWL & 0.600 & 1.011 & 1.113 & 0.517 & 1.037 & 1.255 \\
\hline \multirow[t]{3}{*}{4} & Meyer Peter Muller & HWL & 0.841 & 0.833 & 0.713 & 0.844 & 0.840 & 0.739 \\
\hline & & SWL & 0.806 & 0.833 & 0.713 & 0.758 & 0.840 & 0.739 \\
\hline & & LWL & 0.809 & 0.833 & 0.713 & 0.742 & 0.840 & 0.739 \\
\hline \multirow[t]{3}{*}{5} & Tofaletti & HWL & 0.882 & 0.942 & - & 0.859 & 1.021 & - \\
\hline & & SWL & 0.895 & 0.941 & - & 0.857 & 1.021 & - \\
\hline & & LWL & 0.892 & 0.941 & - & 0.858 & 1.021 & - \\
\hline \multirow[t]{3}{*}{6} & Yang & HWL & 0.567 & 0.689 & 0.899 & 0.548 & 0.751 & 1.206 \\
\hline & & SWL & 0.492 & 0.692 & 0.967 & 0.419 & 0.818 & 1.236 \\
\hline & & LWL & 0.482 & 0.751 & 1.063 & 0.435 & 0.839 & 1.236 \\
\hline
\end{tabular}

Sumber: Hasil Perhitungan

Simulasi Angkutan Sedimen Sebelum Pembangunan Groundsill

Hasil simulasi angkutan sedimen pada kondisi eksisting (sebelum ada bangunan groundsill) dari tahun 2014 sampai dengan tahun 2016 menunjukkan adanya perubahan kondisi dasar sungai yang cukup bervariasi.
Kecenderungan yang terjadi adalah degradasi dasar sungai antara $0,003 \mathrm{~m}$ sampai $3,910 \mathrm{~m}$. Sedangkan agradasi terjadi antara $0,004 \mathrm{~m}$ sampai $1,380 \mathrm{~m}$.

Hasil simulasi angkutan sedimen pada kondisi sebelum pembangunan groundsill dapat dilihat pada Gambar 7 dan Gambar 8.

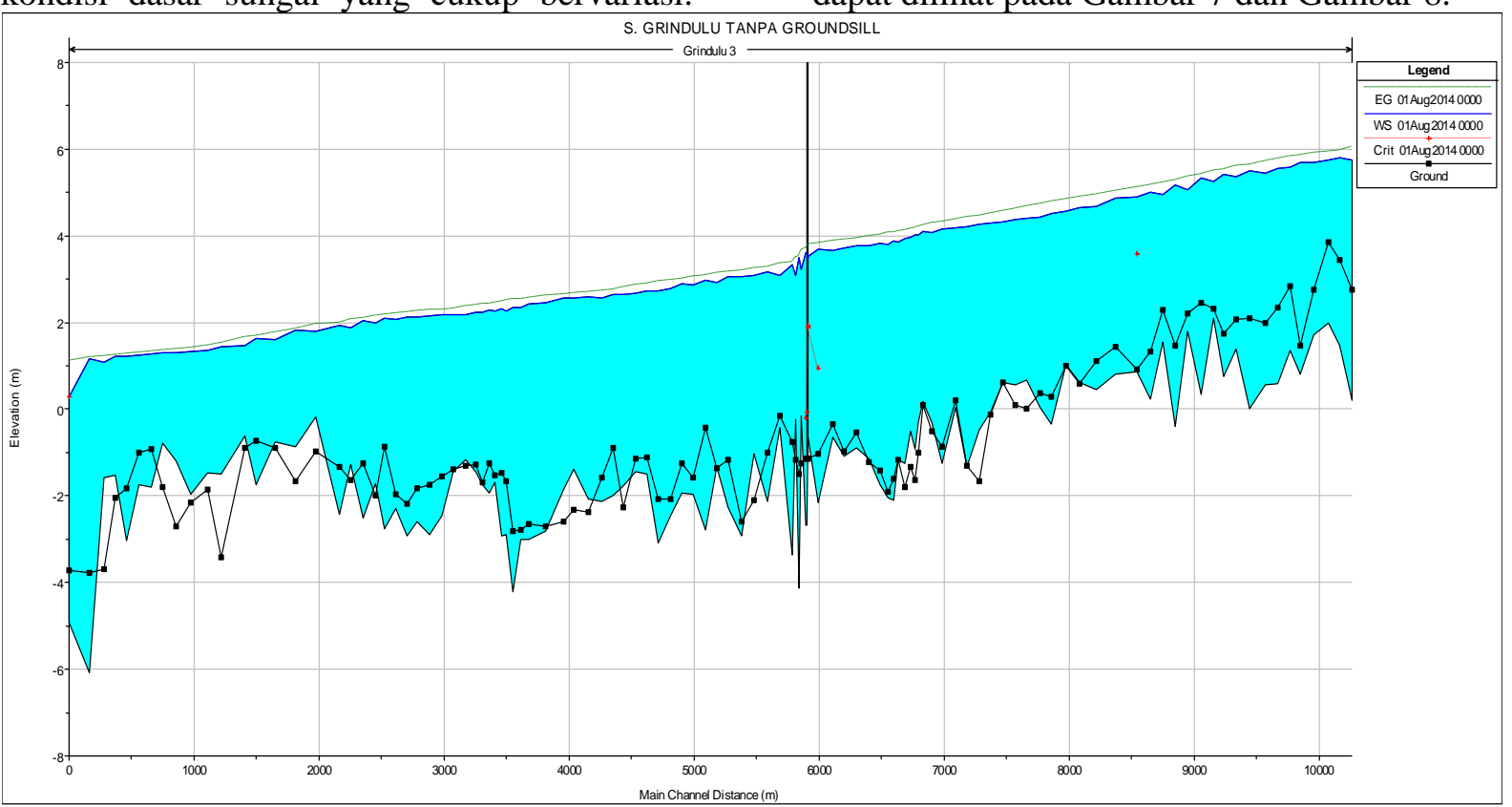

Gambar 7. Profil Muka Air dan Sebaran Sedimen Sungai Grindulu Tahun 2016 Sumber: Hasil Perhitungan 


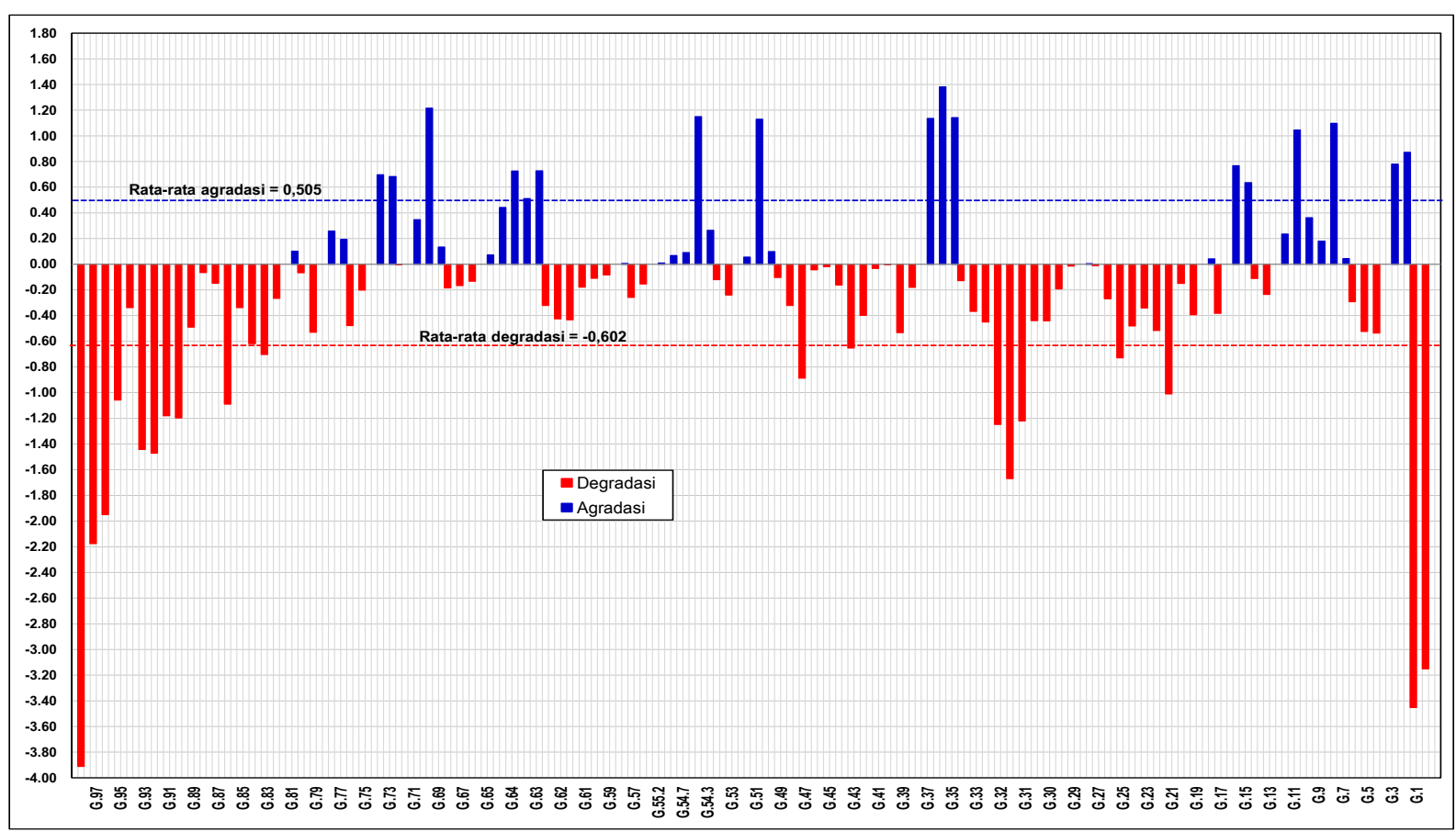

Gambar 8. Grafik Perubahan Dasar Sungai Grindulu Tahun 2016 Tanpa Groundsill Sumber: Hasil Simulasi

\section{Simulasi Angkutan Sedimen Setelah Pembangunan Groundsill}

Untuk mengetahui pengaruh bangunan groundsill beserta penambangan pasir sungai (pengangkutan material ke luar sungai), simulasi dengan metode angkutan sedimen terpilih dilakukan dalam 2 skenario, yaitu:

1. Kondisi morfologi sungai setelah ada bangunan groundsill tanpa penambangan pasir sungai.

2. Kondisi morfologi sungai setelah ada bangunan groundsill dengan penambangan pasir sungai.

Pada kondisi sungai dengan groundsill tanpa adanya penambangan pasir cenderung terjadi degradasi dengan kedalaman antara 0,002 m sampai $3.782 \mathrm{~m}$. Sedangkan agradasi terjadi antara 0,006 m sampai $1,632 \mathrm{~m}$.

Dibandingkan dengan kondisi sebelum adanya groundsill, hasil ini menunjukkan bahwa terjadi peningkatan rata-rata degradasi dasar sungai $(0.602 \mathrm{~m})$ dan terjadi penurunan rata-rata agradasi dasar sungai $(0,505 \mathrm{~m})$.

Hasil simulasi angkutan sedimen pada kondisi sungai dengan groundsill tanpa adanya penambangan pasir dapat dilihat pada Gambar 9 dan Gambar 10.

Berdasarkan analisa, hal ini lebih disebabkan akibat adanya perubahan kondisi dasar sungai pada beberapa ruas di hilir bangunan groundsill. Pembangunan groundsill menyebabkan terjadinya gerusan terhadap dasar sungai di hilir groundsill.
Simulasi selanjutnya pada kondisi sungai dengan groundsill dan penambangan pasir sungai dilakukan dengan mempertimbangkan besarnya jumlah material yang dikeluarkan dari alur sungai oleh kegiatan penambangan.

Besarnya penurunan dasar sungai pada lokasi penambangan diperkirakan berdasarkan kapasitas pengambilan material sungai.

Hasil simulasi angkutan sedimen pada kondisi sungai dengan groundsill dan penambangan pasir dapat dilihat pada Gambar 11 dan Gambar 12.

Dari gambar tersebut diketahui bahwa angkutan sedimen yang terjadi menunjukkan kecenderungan terjadi degradasi dasar sungai antara $0,013 \mathrm{~m}$ sampai $3,954 \mathrm{~m}$. Sedangkan agradasi terjadi antara $0,027 \mathrm{~m}$ sampai 1,232 m. Dibandingkan dengan kondisi tanpa groundsill dan dengan groundsill tanpa penambangan pasir, maka terjadi peningkatan kedalaman rata-rata degradasi dasar sungai. Hal ini disebabkan adanya perubahan kondisi morfologi sungai yang sebelumnya terjadi agradasi menjadi degradasi akibat adanya groundsill maupun akibat penambangan pasir sungai.

Selain itu, dari hasil simulasi dapat diketahui bahwa penurunan dasar sungai yang besar lebih banyak terjadi pada lokasi-lokasi tikungan luar sungai (G.62, G.79, G.31+50), di hilir groundsill, di hulu dan hilir pilar Jembatan Arjowinangun (G.55 dan G.55+20) dan di muara sungai. 


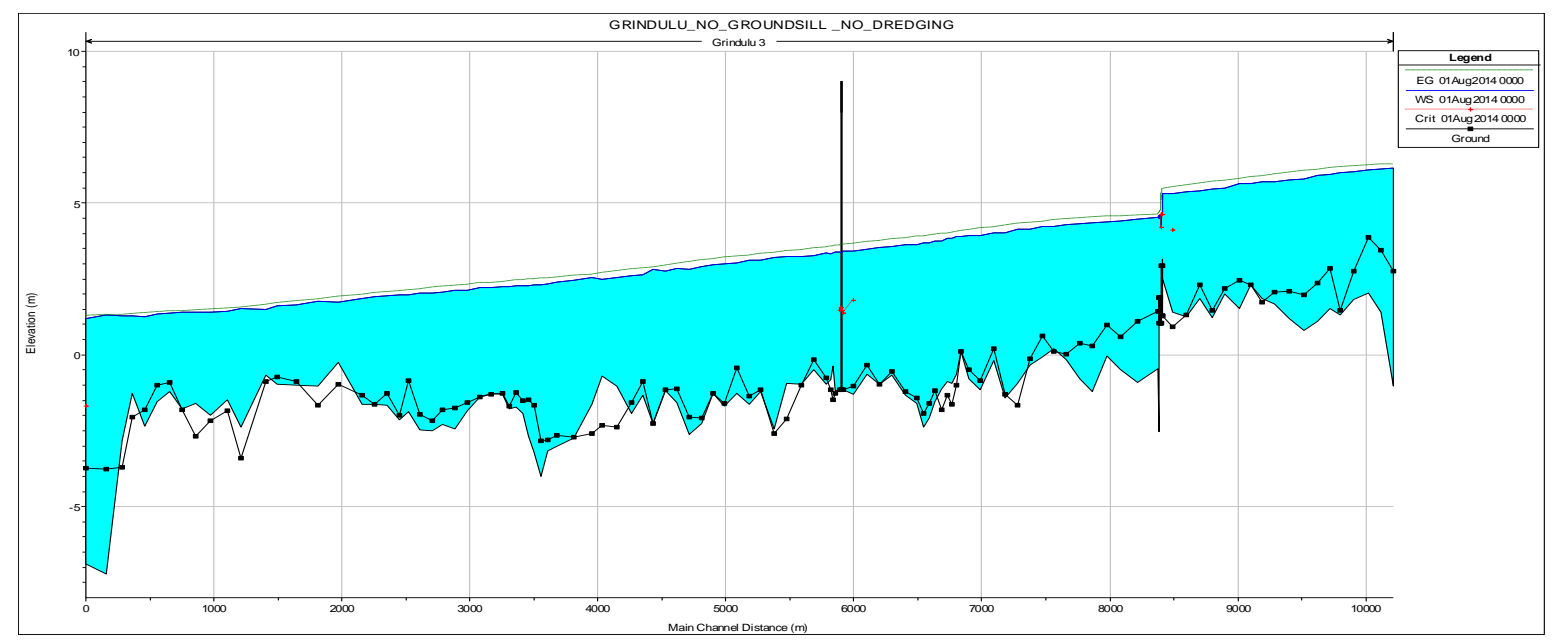

Gambar 9. Profil Muka Air dan Sebaran Sedimen Sungai Grindulu Tahun 2016 Dengan Groundsill Tanpa Pengambilan Pasir

Sumber: Hasil Simulasi

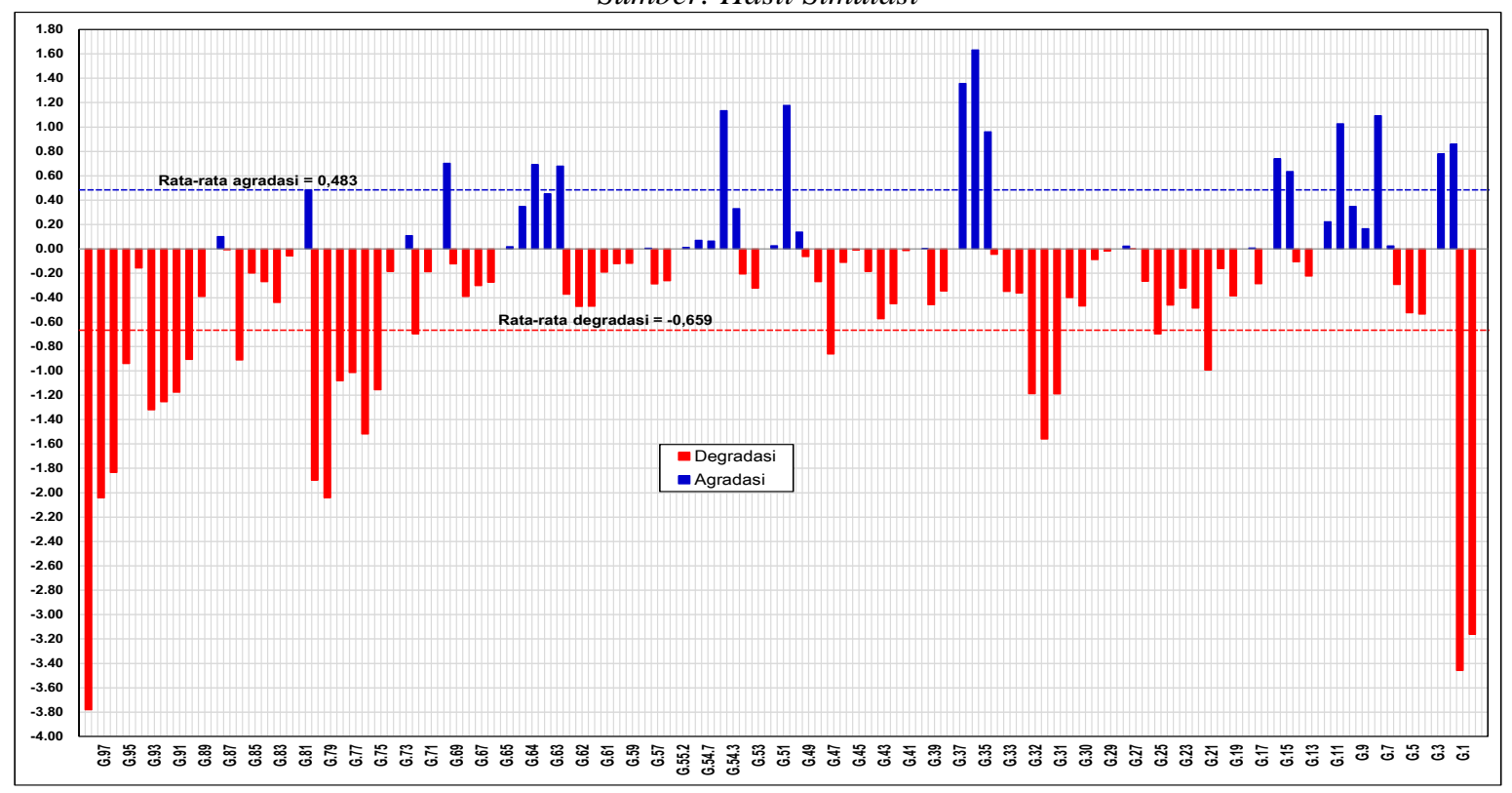

Gambar 10.Grafik Perubahan Dasar Sungai Grindulu Tahun 2016 Dengan Groundsill Tanpa Penambangan Pasir Sungai

Sumber: Hasil Simulasi

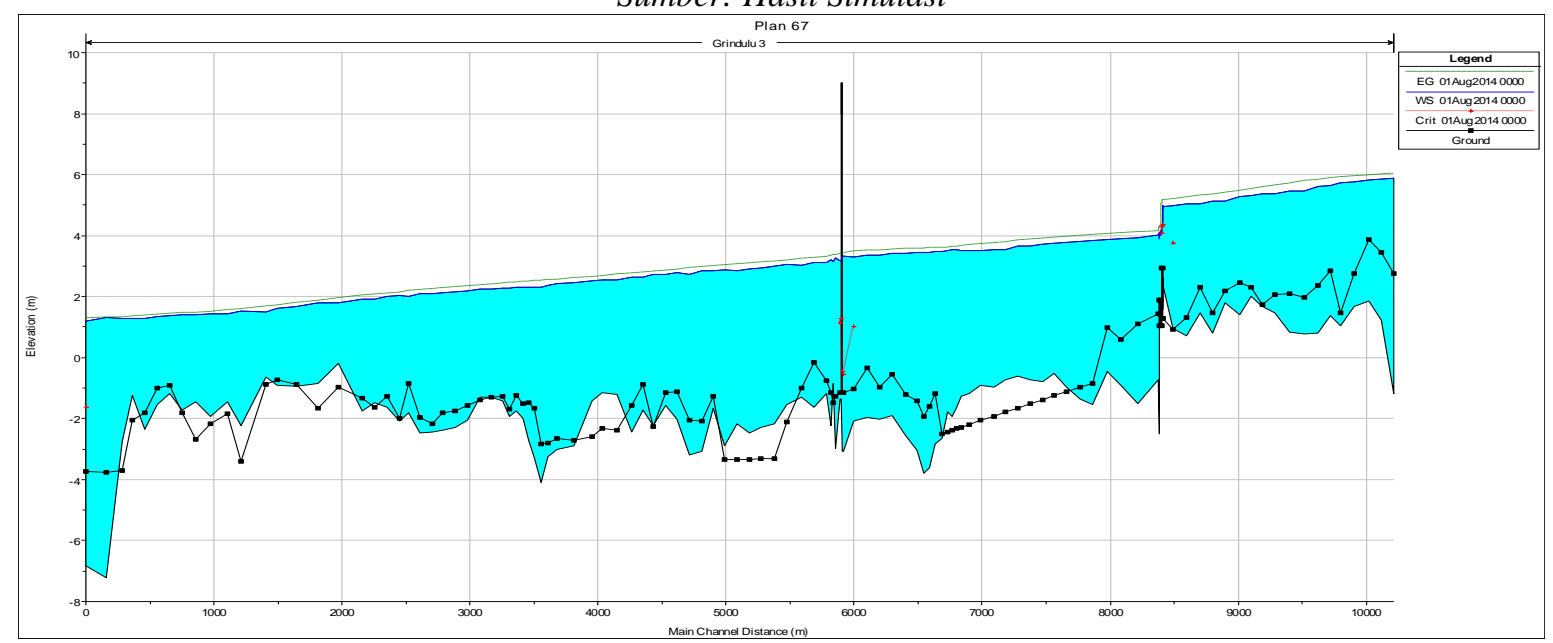

Gambar 11. Profil Muka Air dan Sebaran Sedimen Sungai Grindulu Tahun 2016 Dengan Groundsill dan Penambangan Pasir Sungai

Sumber: Hasil Simulasi 


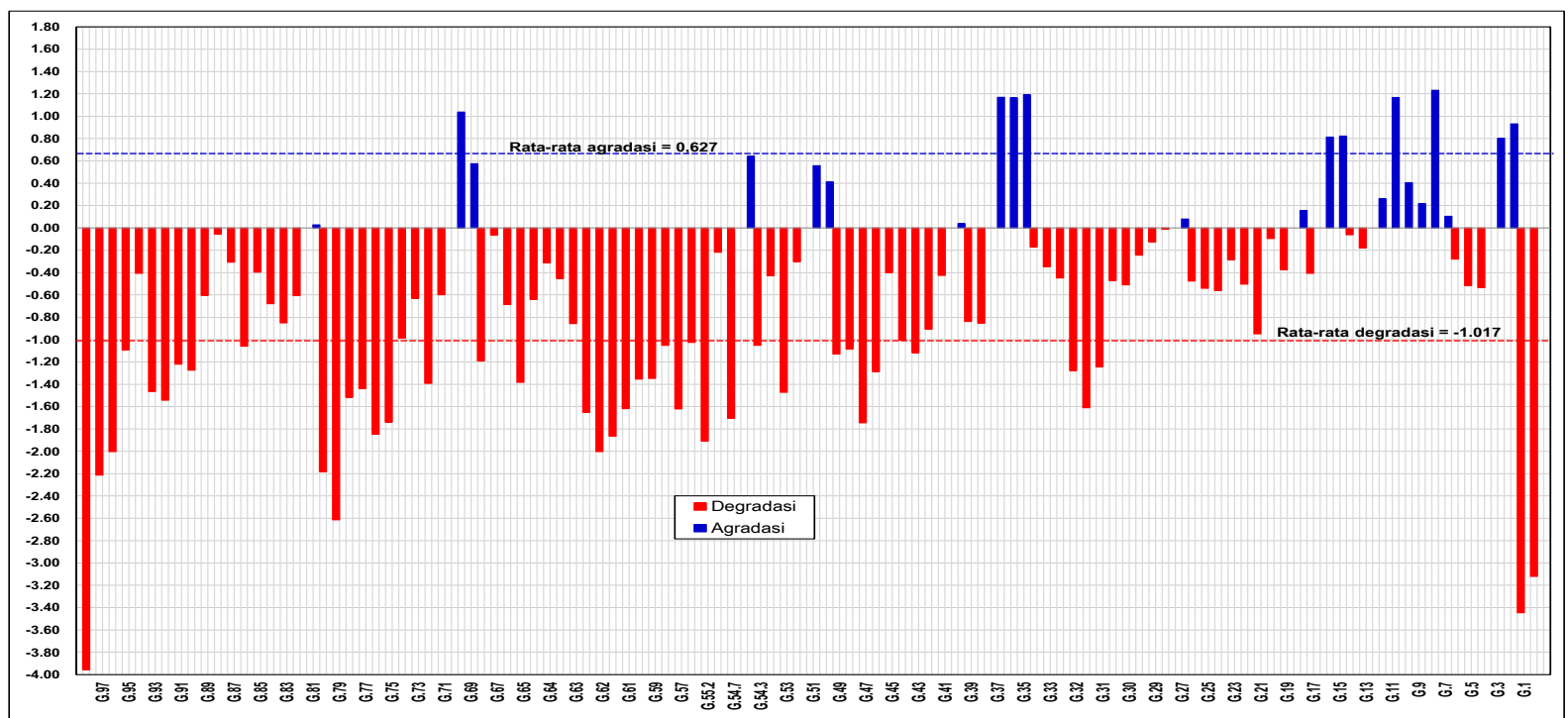

Gambar 12. Grafik Perubahan Dasar Sungai Grindulu Tahun 2016 Dengan Groundsill dan Penambangan Pasir Sungai

\section{Sumber: Hasil Simulasi}

\section{Evaluasi dan Rekomendasi Lokasi Penambangan Pasir Sungai}

Hasil dari simulasi angkutan sedimen menunjukkan dalam kurun waktu 2 tahun, pengambilan pasir sungai telah meningkatkan degradasi dasar sungai rata-rata $1,017 \mathrm{~m}$.

Berdasarkan hasil tersebut, maka lokasi penambangan eksisting direkomendasikan untuk dihentikan bertahap. Hal ini diperkuat dengan hasil penelusuran lapangan yang menunjukkan bahwa jumlah material sungai di lokasi penambangan eksisting sudah terbatas.

Hasil simulasi juga menunjukkan bahwa ruas G.35-G.37 selalu mengalami agradasi (pengendapan) baik sebelum pembangunan groundsill, setelah pembangunan groundsill tanpa penambangan pasir maupun setelah pembangunan groundsill dan penambangan pasir. Sehingga direkomendasi lokasi penambangan pasir baru adalah antara ruas G.34-G.38 yang terletak di Desa Ploso. Lokasi ini dipilih karena deposit sedimen yang terjadi paling besar dan letaknya jauh dari bangunan sungai. Besarnya kapasitas pengambilan pasir sungai yang disarankan pada lokasi penambangan baru adalah $65 \mathrm{~m}^{3} / \mathrm{hari}$.

\section{Simulasi Prediksi Angkutan Sedimen Periode 5 dan 10 Tahun}

Dalam melakukan simulasi angkutan sedimen periode 5 dan 10 tahun yang akan datang dipertimbangkan pengaruh perubahan iklim terhadap debit sungai dan tinggi muka air laut. Adapun debit dan tinggi muka air laut yang digunakan dalam simulasi ini adalah:

- Debit tahun $2021=513,49 \mathrm{~m}^{3} / \mathrm{dt}$

- Debit tahun $2026=516,05 \mathrm{~m}^{3} / \mathrm{dt}$

- TML tahun $2021 \quad=1,212 \mathrm{~m}$

- TML tahun $2026=1,223 \mathrm{~m}$

Hasil simulasi angkutan sedimen periode 5 dan 10 tahun yang akan datang dapat dilihat pada Gambar 13 sampai dengan Gambar 16.

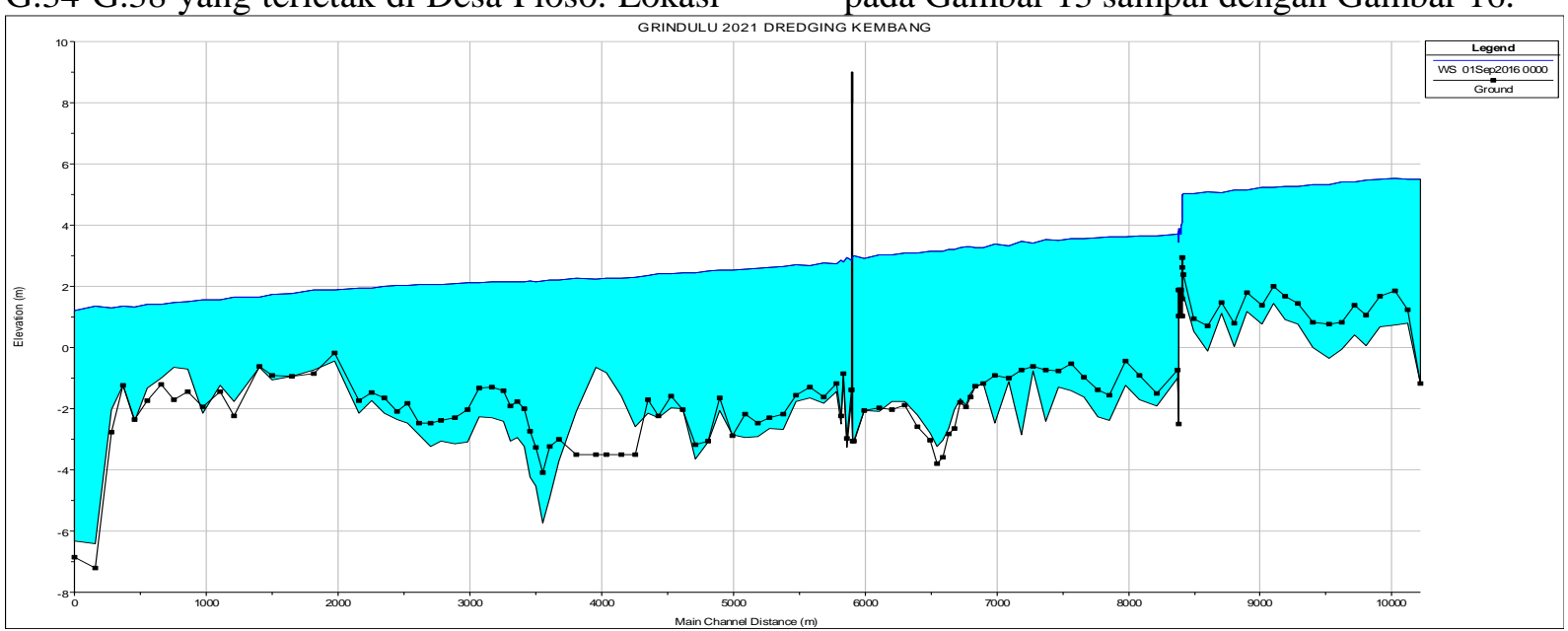

Gambar 13. Profil Muka Air dan Sebaran Sedimen Sungai Grindulu Tahun 2021 


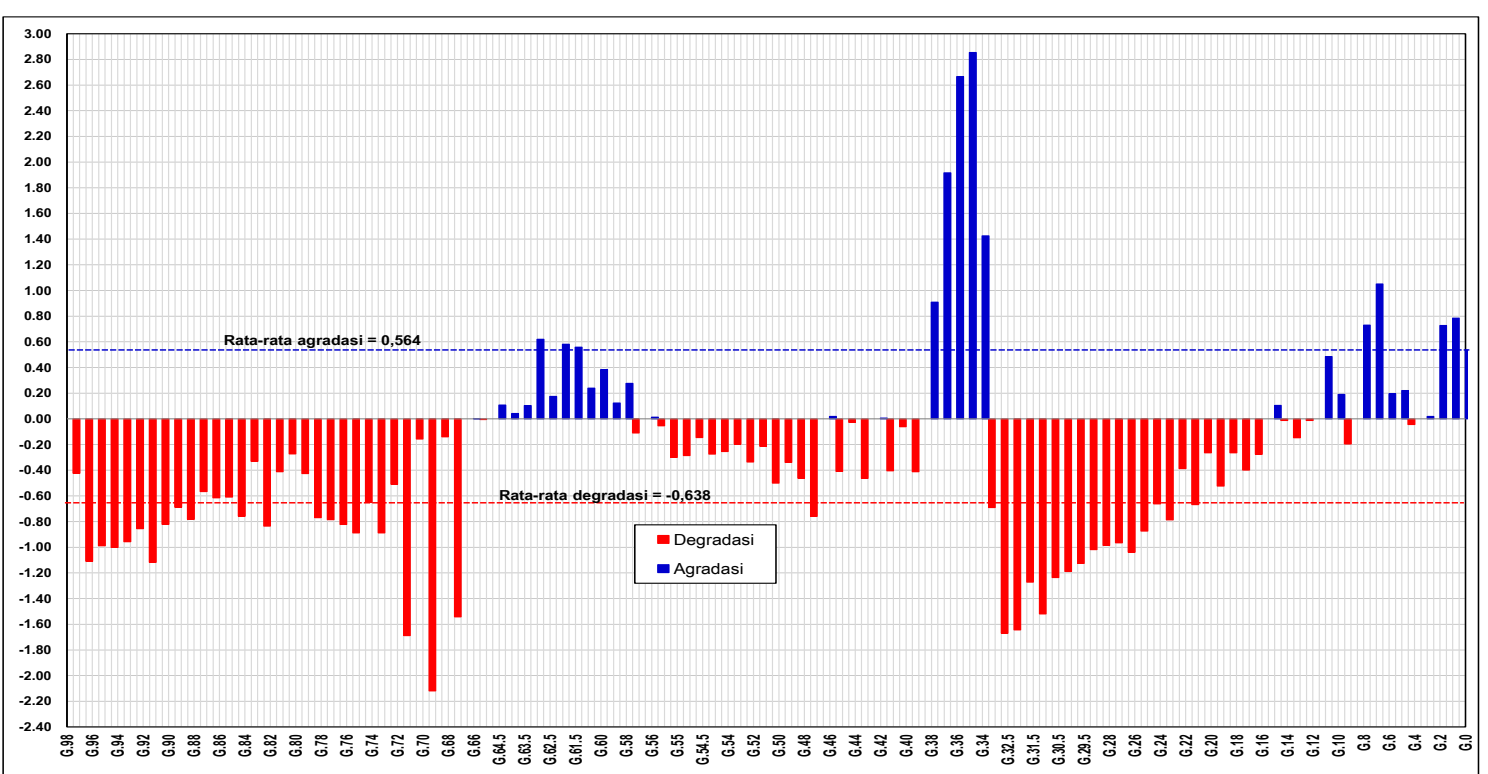

Gambar 14. Grafik Perubahan Dasar Sungai Grindulu Tahun 2021

Sumber: Hasil Simulasi

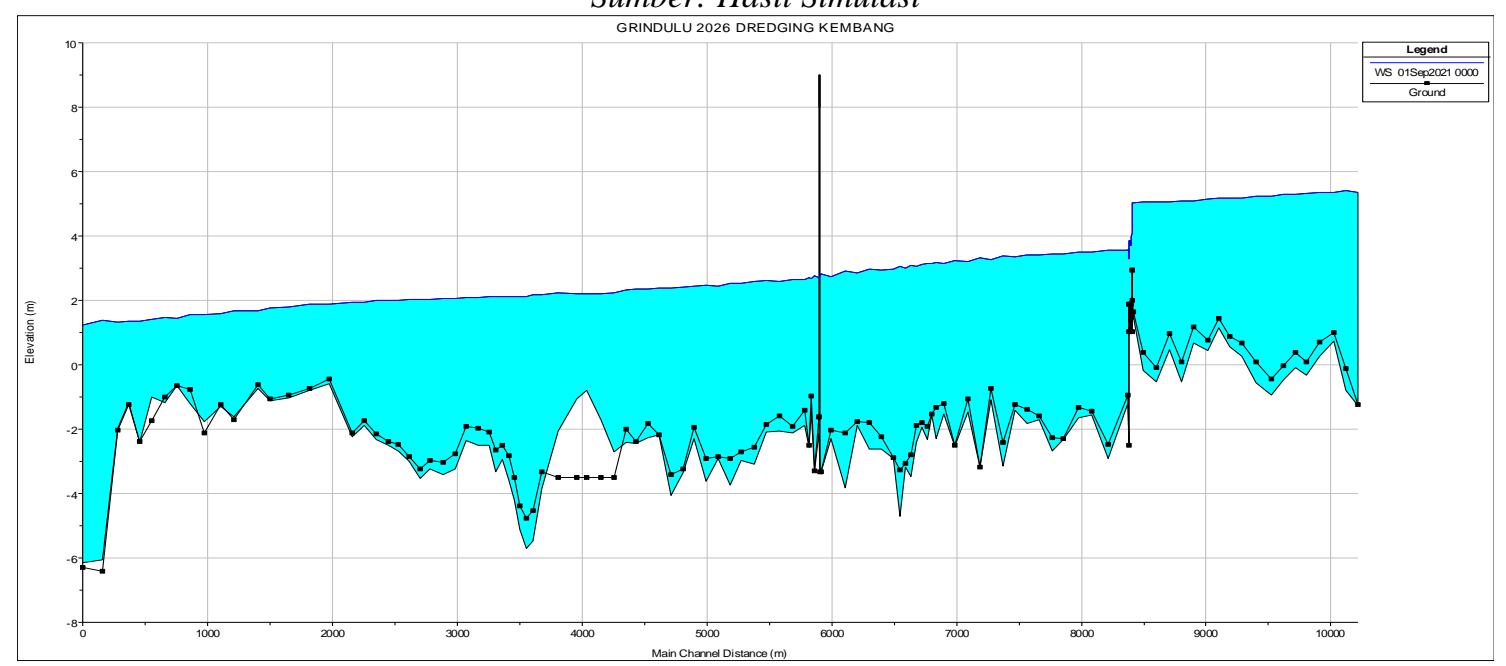

Gambar 15. Profil Muka Air dan Sebaran Sedimen Sungai Grindulu Tahun 2026 Sumber: Hasil Simulasi

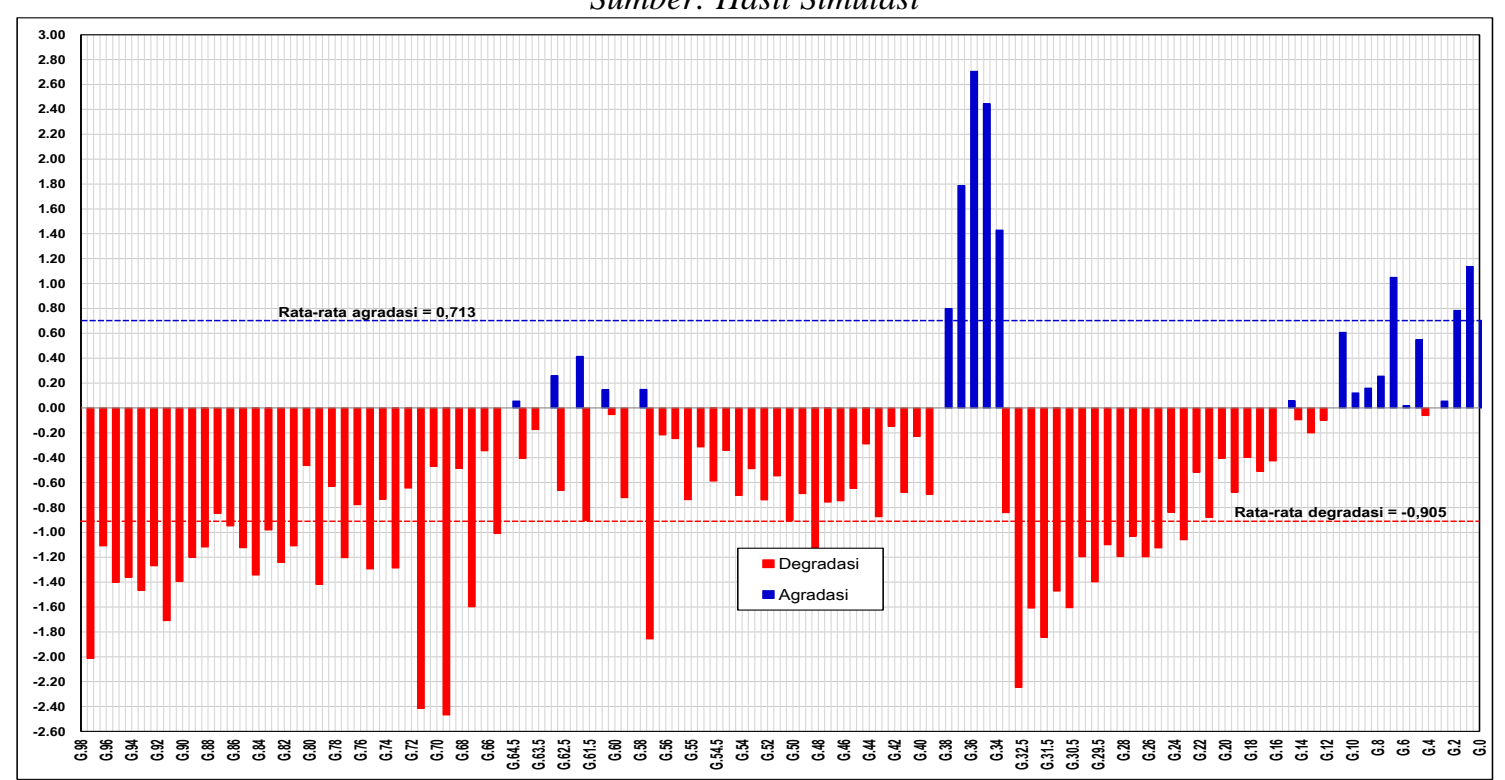

Gambar 16. Grafik Perubahan Dasar Sungai Grindulu Tahun 2026

Sumber: Hasil Simulasi 
Berdasarkan hasil simulasi angkutan sedimen di atas diperoleh bahwa rata-rata penurunan elevasi dasar sungai pada periode 5 dan 10 tahun yang akan datang terhadap kondisi tahun 2016 secara berturut-turut adalah sebesar 0,569 $\mathrm{m}$ dan $0,846 \mathrm{~m}$. Sedangkan rata-rata kenaikan elevasi dasar sungai pada periode tersebut secara berturut-turut adalah sebesar $0,487 \mathrm{~m}$ dan $0,545 \mathrm{~m}$.

Selain hal tersebut, dari hasil simulasi diketahui bahwa baik pada tahun 2021 maupun tahun 2026 pengendapan sedimen paling besar terjadi antara ruas G.34 sampai G.38. Hal tersebut dapat diartikan bahwa rekomendasi lokasi penambangan pasir sungai yang baru telah sesuai karena akumulasi sedimen selalu terjadi pada ruas sungai tersebut.

\section{KESIMPULAN DAN SARAN}

\section{Kesimpulan}

berikut:

1. Pola sebaran sedimen yang terjadi sampai dengan tahun 2016 tanpa adanya groundsill menunjukkan kecenderungan yang terjadi adalah degradasi dengan kedalaman ratarata $0,602 \mathrm{~m}$. Sedangkan agradasi terjadi dengan ketinggian rata-rata $0,505 \mathrm{~m}$.

2. Pola sebaran sedimen yang terjadi pada sampai dengan tahun 2016 dengan adanya groundsill dan penambangan pasir menunjukkan peningkatan kejadian degradasi dengan kedalaman rata-rata $1,017 \mathrm{~m}$. Sedangkan agradasi dengan ketinggian rata-rata $0,627 \mathrm{~m}$.

3. Hasil simulasi sampai dengan tahun 2016 menujukkan akumulasi sedimen paling besar terjadi pada ruas sungai G.34 sampai dengan G.38 dengan panjang $585 \mathrm{~m}$.

4. Hasil simulasi angkutan sedimen periode tahun 2021 dan 2026 menunjukkan hal-hal sebagai berikut:

a. Rata-rata penurunan elevasi dasar sungai sampai dengan tahun 2021 terhadap kondisi tahun 2016 adalah sebesar $0,638 \mathrm{~m}$ atau $0,128 \mathrm{~m} /$ tahun.

b. Rata-rata penurunan elevasi dasar sungai sampai dengan tahun 2026 terhadap kondisi tahun 2016 adalah sebesar $0,905 \mathrm{~m}$ atau $0,0905 \mathrm{~m} /$ tahun.

c. Rata-rata kenaikan elevasi dasar sungai pada tahun 2021 dan 2026 secara berturut-turut adalah sebesar $0,564 \mathrm{~m}$ dan $0,713 \mathrm{~m}$. d. Akumulasi sedimen terbesar terjadi pada ruas sungai antara G.34 sampai G.38.

\section{Saran}

Beberapa saran yang dapat penulis berikan dalam studi ini diantaranya:

1. Untuk penelitian selanjutnya, data pengukuran untuk kalibrasi (setelah simulasi) sebaiknya memiliki jumlah titik pengukuran yang sama dengan sebelum simulasi.

2. Perlu dilakukan pemantauan/pengukuran konsentrasi sedimen yang lebih panjang untuk mendapatkan sejumlah data yang lebih mewakili kondisi lapangan.

3. Direkomendasikan lokasi penambangan pasir baru berdasarkan akumulasi sedimen paling besar, yaitu pada ruas sungai G.34 sampai G.38.

4. Harus ada monitoring/pemantauan secara berkala terhadap kegiatan penambangan pasir sungai meliputi lokasi penambangan, batas areal penambangan, jumlah/kapasitas material sungai yang ditambang, dan elevasi penambangan minimum yang diperbolehkan.

5. Dilakukan evaluasi secara berkala untuk mengetahui ketersediaan jumlah sedimen secara pasti.

6. Perlu dilakukan penelitian pada ruas sungai Grindulu lain untuk mengetahui lokasilokasi yang potensial sebagai lokasi penambangan pasir dalam rangka memenuhi kebutuhan akan material konstruksi yang berasal dari sungai.

\section{DAFTAR PUSTAKA}

Asdak, C. 2007. Hidrologi dan Pengelolaan Daerah Aliran Sungai. Yogyakarta: Gadjah Mada University Press.

[IPCC] Intergovernmental Panel on Climate Change. 2007. Climate Change and Water. Cambridge University Press. USA.

Keshavarzy, A. and Nabavi, S.H., 2006. Dominant Discharge In The Kor River Fars Province, Iran. Tenth International Water Technology Conference, IWTC10. Alexandria. Egypt.

Triatmodjo, Bambang. 2010. Hidrologi Terapan. Yogyakarta: Beta Offset.

Wolman M.G. and Leopold, L.B., 1957. River Flood Plains: Some Observations on Their Formation. U.S. Geology Survey, Prof. Paper No. 282-C. 